\title{
Multi-Element Analysis of Spanish Date Palm (Phoenix dactylifera L.) by Inductively Coupled Plasma-Based Techniques. Discrimination Using Multivariate Statistical Analysis
}

Shaymaa S. Abdrabo 1

Guillermo Grindlay 1

Luis Gras 1

Juan Mora $1, *$

1 Department of Analytical Chemistry, Nutrition and Food

Sciences, University of Alicante, P.O. Box 99, 03080 Alicante, Spain

\section{Abstract}

The elemental analysis of Spanish palm dates by inductively coupled plasma atomic emission spectrometry and inductively coupled plasma mass spectrometry is reported for the first time. To complete the information about the mineral composition of the samples, $\mathrm{C}, \mathrm{H}$, and $\mathrm{N}$ are determined by elemental analysis. Dates from Israel, Tunisia, Saudi Arabia, Algeria and Iran have also been analyzed. The elemental composition have been used in multivariate statistical analysis to discriminate the dates according to its geographical origin. A total of 23 elements (As, Ba, C, Ca, Cd, Co, Cr, Cu, $\mathrm{Fe}, \mathrm{H}, \mathrm{In}, \mathrm{K}, \mathrm{Li}, \mathrm{Mg}, \mathrm{Mn}, \mathrm{N}, \mathrm{Na}, \mathrm{Ni}, \mathrm{Pb}, \mathrm{Se}, \mathrm{Sr}, \mathrm{V}$, and $\mathrm{Zn}$ ) at concentrations from major to ultra-trace levels have been determined in 13 date samples (flesh and seeds). A careful inspection of the results indicate that Spanish samples show higher concentrations of $\mathrm{Cd}, \mathrm{Co}, \mathrm{Cr}$, and $\mathrm{Ni}$ than the remaining ones. Multivariate statistical analysis of the obtained results, both in flesh and seed, indicate that the proposed approach can be successfully applied to discriminate the Spanish date samples from the rest 
of the samples tested.

\section{Keywords}

Date palm

Elemental composition

ICP-AES

ICP-MS

Multivariate analysis

Origin classification

\section{Electronic supplementary material}

The online version of this article (doi: 10.1007/s12161-014-0011-8 ) contains supplementary material, which is available to authorized users.

\section{Introduction}

Palm date (Phoenix dactylifera $\mathrm{L}$.) is one of the oldest cultivated trees, and its fruit is being used as foodstuff for about 6,000 years. Nowadays, date is one of the most consumed fruit in the Arabian countries (Ismail et al. 2006). Date palm is a particularly important crop in arid and semi-arid regions of the world, being Egypt, Saudi Arabia, Iran, United Arab Emirates, and Algeria the main producing countries. World dates production has increased from 4.4 million tons in 1993 to 7.5 million tons in 2012, and it is expected to continue increasing in the future (FAO).

Several studies about date composition have been recently reviewed (Tang et al. 2013). Carbohydrates are the major component of date fruit, reaching more than $70 \%$ (being sucrose, glucose, and fructose the main sugars) (Ahmed et al. 1995; Myhara et al. 1999; Elleuch et al. 2008; Khan et al. 2008; Amira et al. 2011). Dates show high amounts of dietary fiber, ranging between 6 to $25 \%$ in date flesh (Ahmed et al. 1995; Elleuch et al. 2008; Al-Farsi et al. 2005; al-Hooti et al. 1997) and up to $80 \%$ in seeds (Al-Farsi and Lee 2008a), proteins (Elleuch et al. 2008; Hamada et al. 2002; Sahari et al. 2007; Ishurd et al. 2004), lipids (Amira et al. 2011; Hamada et al. 2002; Sahari et al. 2007; Besbes et al. 2004; Al-Shahib and Marshall 2003), vitamins, carotenoids (Boudries et al. 2007), $>$ and phenolic compounds (Bigliari et al. 2008). Dates are also considered a good source of essential and non-essential elements (Tang et al. 2013). Thus, $100 \mathrm{~g}$ of dates approximately 
provides up to $24 \% \mathrm{Mg}, 33 \% \mathrm{~K}, 13 \% \mathrm{Mn}, 46 \% \mathrm{Cu}$, and $20 \% \mathrm{Cr}$ of the daily recommended dietary allowance for adults. Calcium, $\mathrm{K}, \mathrm{Mg}, \mathrm{Na}$, and $\mathrm{P}$ are the major elements present in dates flesh and seed (Ahmed et al. 1995; Elleuch et al. 2008; Khan et al. 2008; Besbes et al. 2004) whereas Cd, Co, $\mathrm{Cr}, \mathrm{Cu}, \mathrm{Fe}, \mathrm{Mn}, \mathrm{Ni}, \mathrm{Pb}, \mathrm{Se}$, and $\mathrm{Zn}$ are found at ultra-trace levels (Al-Farsi et al. 2005 ; Mohamed 2000; Pillay et al. 2002). Dates' elemental composition strongly depends on the ripening stage, variety, and location (Tang et al. 2013 ). Thus, Khan et al. (2008) observed that the elemental content (Ca, Co, $\mathrm{Cu}, \mathrm{Fe}, \mathrm{K}, \mathrm{Na}, \mathrm{Ni}, \mathrm{Pb}$, and $\mathrm{Zn}$ ) increases (especially $\mathrm{Cu}$ and $\mathrm{K}$ ) with maturation. Amira et al. (2011) afforded similar conclusions. However, Ahmed et al. (1995) and Rastegar et al. (2012) concluded that, in general, mineral contents decreased as fruit matured from the kimri to the tamar stage of development. Sahari et al. (2007) studied the chemical content of Ca, K, and $\mathrm{Mg}$ in 34 date varieties (Rutab ripening stage) of the same location and observed differences among varieties. Williams et al. (2005) investigated some trace elements in date fruit, leaves, and soil and observed that the levels of some selected elements in leaves ( $\mathrm{Ba}$ and $\mathrm{La})$ and fruit $(\mathrm{Tl})$ were related to those in the soil.

\section{AQ1}

AQ2

Chemical analysis of foodstuff combined with multivariate statistical techniques is a usually deployed tool for provenance determination and the related detection of fraud or adulteration (Pohl 2007). Multivariate analysis has been employed in date analysis for different purposes (e.g., date classification according to their sugar (Khan et al. 2008), antioxidant (Abbas et al. 2008), and volatile compositions (Amira et al. 2011); to evaluate the effect of long-term storage on the antioxidant activity of dates (Bigliari et al. 2009); and to asses phenotypic diversity (Mohamed Ahmed et al. 2011)). Khan et al. (2008) were able to discriminate the origin of seven date samples (four from Pakistan and three foreign varieties) attending to its elemental composition ( $\mathrm{Ca}, \mathrm{Co}, \mathrm{Cu}, \mathrm{Fe}, \mathrm{K}, \mathrm{Na}, \mathrm{Ni}, \mathrm{Pb}$, and $\mathrm{Zn}$ ) and cluster analysis.

Elche (city located at the south-east of Spain) has the most important palm cultivation area in Europe with about 250,000 palm trees. Due to this reason, UNESCO declared in 2000 the palm grove of Elche a World Heritage Site. Most of the dates cultivated in Elche show morphological likeness to different North African cultivars such as Medjool or Deglet Nour. However, the extremely high genetic diversity of palm trees gives rise to dates with no 
defined variety (Johnson et al. 2013 ). Very little information is available about the chemical composition and nutritional characteristics of the Spanish dates. Amorós et al. (2009) determined the total antioxidant activity, total phenolics, sugars, and organic acids in date fruit from seven date samples at different maturation stages in order to obtain information about differences due to phenotypic variability. Martín-Sánchez et al. (2014a, b) investigated the nutritive, physicochemical, and technological characteristics of several intermediate food products from Spanish dates. However, no information about the mineral composition of dates from Elche has been reported up to date.

The aim of the present work is to determine, for the first time, the mineral composition of dates from Elche's Palm Grove (Spain). Results are used in multivariate statistical analysis to establish differences and similarities between Spanish dates and those from different origins (Israel, Tunisia, Saudi Arabia, Algeria, and Iran) and varieties (Medjool, Hayani, Barhi, Deglet Nour, and Perny).

\section{Material and Methods}

\section{Reagents}

High purity water (i.e., with conductivity lower than $18 \mathrm{M} \Omega / \mathrm{cm}$ ) obtained from a Milli-Q water system (Millipore Inc., Paris, France) and nitric acid (trace select TM, Fluka Chemie GmbH, Switzerland) were used throughout the work. Inductively coupled plasma (ICP) standards were prepared in nitric acid $10 \%(w / w)$ using the appropriate set of mono-element stock solutions (Merck, Darmstadt, Germany). A certified standard $(\mathrm{H}=6.71 \%, \mathrm{C}=71.09 \%$, and $\mathrm{N}=10.36 \%$ ) of acetanilide (Carlo-Erba, Sabadell, Spain) was used for calibration in elemental analysis.

\section{Samples}

Thirteen samples of dates of different varieties and origins were analyzed (Fig. S1 in supplementary data): six from Spain (Elche, unknown varieties); three from Israel (Medjool, Hayani, and Barhi varieties); and one from Tunisia (Deglet Nour), Saudi Arabia (Perny), Algeria (Deglet Nour), and Iran (unknown variety). All samples were analyzed in the so-called Rutab ripening stage with the exception of Israel Medjool and Saudi Arabia (Perny) that were analyzed in the Tamer one. Both ripening stages are the usually employed for human consumption. Dates from Spain (Elche) were directly obtained from 
local producers and the rest from different import companies that guarantee the origin traceability.

\section{Sample Pre-Treatment}

Five kilograms of each date sample was collected. Samples were thoroughly washed in running tap water to eliminate any potential contamination from the date surface, and then properly dried. Seeds were separated from date flesh and then rinsed with deionized water. Flesh samples were lyophilized (model Cryodos-80, Telstar, Tarrasa, Spain: temperature $-69.8{ }^{\circ} \mathrm{C}$, vacuum $1.2 \times$ $10^{-3}$ bar for 3 days). Dried samples were grinded with carbide-coated blades to avoid metal contamination (IKA-Werke GmbH \& Co. KG, Staufen, Germany) and then stored in closed properly labeled polyethylene vessels at $-21^{\circ} \mathrm{C}$.

A microwave-assisted digestion procedure was carried out using a microwave system (model MARS 5, CEM Corporation, Matthews, USA) operating at $1,200 \mathrm{~W}$. Once reached the selected conditions (i.e., $200{ }^{\circ} \mathrm{C}$ or $300 \mathrm{psi}$ ) using a 10 -min ramp, the microwave program was hold for $10 \mathrm{~min}$. Aliquots of $0.5 \mathrm{~g}$ of each sample (flesh or seed) were treated with $10 \mathrm{~mL}$ of concentrated $\mathrm{HNO}_{3}$ in a Teflon vessel (model xp-1500 plus, CEM Corporation, Matthews, USA). After cooling to room temperature, reactors were opened to eliminate nitrous vapors and the remaining solution was diluted up to the appropriate volume (i.e., 25 or $50 \mathrm{~mL}$ for the solutions measured by ICP atomic emission spectrometry (ICP-AES) and ICP mass spectrometry (ICP-MS), respectively). In all cases, the digestion was complete and no solid residues were observed. To avoid cross-contamination, Teflon vessels were carefully cleaned with nitric acid before to proceed with the sample treatment.

\section{Instrumentation}

Calcium, $\mathrm{Cu}, \mathrm{Fe}, \mathrm{K}, \mathrm{Mg}, \mathrm{Mn}, \mathrm{Na}, \mathrm{Sr}$, and $\mathrm{Zn}$ were determined by ICP-AES (model Optima 4300DV, PerkinElmer, Shelton, CT, USA). Ultra-trace elements (i.e., $\mathrm{As}, \mathrm{Ba}, \mathrm{Cd}, \mathrm{Co}, \mathrm{Cr}, \mathrm{Li}, \mathrm{Ni}, \mathrm{Pb}, \mathrm{Se}$, and $\mathrm{V}$ ) were determined by ICP-MS (model VG PQ, Thermo Elemental, Winsford, Cheshire, UK).

Table 1 shows the operating conditions employed in both techniques. Table 1 also gathers the wavelengths and isotopes registered in ICP-AES and ICP-MS, respectively. Selection was performed in terms of sensitivity and absence of interferences. 


\section{Table 1}

ICP-AES and ICP-MS operating conditions

\begin{tabular}{|c|c|c|}
\hline & ICP-AES & ICP-MS \\
\hline Plasma forward power (W) & 1,300 & 1,350 \\
\hline \multicolumn{3}{|l|}{ Argon flow rate $(\mathrm{L} / \mathrm{min})$} \\
\hline Plasma & 15 & 14 \\
\hline Auxiliary & 0.2 & 0.92 \\
\hline Nebulizer & 0.6 & 0.82 \\
\hline Sample uptake rate $(\mathrm{mL} / \mathrm{min})$ & 1 & 0.8 \\
\hline View & Axial & - \\
\hline Number of replicates & 3 & 3 \\
\hline Scanning mode & - & Peak jump \\
\hline Points per peak & - & 3 \\
\hline Dwell time $(\mu \mathrm{s})$ & - & 150 \\
\hline Number of sweeps & - & 40 \\
\hline \multirow[t]{13}{*}{ Element (wavelength, nm)/nuclide } & $\mathrm{Ca}(317.933)$ & ${ }^{75} \mathrm{As}^{+}$ \\
\hline & $\mathrm{Cu}(224.700)$ & ${ }^{138} \mathrm{Ba}^{+}$ \\
\hline & $\mathrm{Fe}(238.204)$ & ${ }^{114} \mathrm{Cd}^{+}$ \\
\hline & $\mathrm{K}(766.490)$ & ${ }^{59} \mathrm{Co}^{+}$ \\
\hline & $\operatorname{Mg}(280.271)$ & ${ }^{52} \mathrm{Cr}^{+}$ \\
\hline & $\operatorname{Mn}(257.610)$ & ${ }^{115} \mathrm{In}^{+}$ \\
\hline & $\mathrm{Na}(588.995)$ & ${ }^{7} \mathrm{Li}^{+}$ \\
\hline & Sc $(357.253)$ & ${ }^{60} \mathrm{Ni}^{+}$ \\
\hline & $\operatorname{Sr}(407.771)$ & ${ }^{208} \mathrm{~Pb}^{+}$ \\
\hline & Zn (206.200) & ${ }^{187} \mathrm{Re}^{+}$ \\
\hline & & ${ }^{45} \mathrm{Sc}^{+}$ \\
\hline & & ${ }^{82} \mathrm{Se}^{+}$ \\
\hline & & ${ }^{51} \mathrm{~V}^{+}$ \\
\hline
\end{tabular}

To obtain more complete information about elemental composition of date 
samples, C, H, and $\mathrm{N}$ were determined by means elemental analysis (Flash EA 1112, Thermo Finnigan, Winsford, Cheshire, UK).

\section{Calibration Strategy}

The analysis of date samples by ICP-AES and ICP-MS was based on external calibration using matrix-matched standard solutions and internal standardization to correct for matrix effects and signal drift. Standards were prepared in nitric acid (i.e., $10 \%(w / w)$ and $5 \%(w / w)$ in ICP-AES and ICP-MS, respectively). Scandium was used as internal standard in ICP-AES. Three internal standards (Sc, In, and Re) were tested in ICP-MS to cover the whole $\mathrm{m} / \mathrm{z}$ range (Grindlay et al. 2014). For each nuclide, the selection was based on $\mathrm{m} / \mathrm{z}$ closeness (Vanhaecke et al. 1992). The concentration of each internal standard in the resulting sample solution was 1 and $0.1 \mathrm{mg} / \mathrm{L}$ for ICP-AES and ICP-MS, respectively.

A certified standard of acetanilide was used for calibration in the analysis of $\mathrm{C}, \mathrm{H}$, and N. Analytical figures of merit.

Analytical Figures of Merit

To evaluate the analytical method proposed for the elemental analysis of dates by ICP-based techniques, some analytical figures of merit were estimated as follows:

\section{Accuracy}

A recovery test was performed to evaluate method accuracy because no certified date material is available for validating the multi-element analysis. Experiments were carried out using four different date samples: Elche3, Elche6, Tunisia Deglet Nour, and Israel Medjool. Taking into account the concentrations reported for each analyte in dates (Tang et al. 2013), samples were spiked at different concentration levels $(0.1,10,100$, and $500 \mathrm{mg} / \mathrm{L})$ with a multi-element solution prior to the mineralization step. Experiments were performed in quintuplicate.

\section{Precision}

Precision was estimated by means of the relative standard deviation (RSD) calculated from the elemental concentrations obtained after the analysis of the five independent replicates of each date sample. Therefore, RSD takes into account not only the precision of the analytical method but also the homogeneity of the sample. 


\section{Limits of Detection (LoD) and Quantification (LoQ)}

The method LoDs and LoQs were estimated for all the elements using the three and ten times signal blank standard deviation criteria (ten replicates), respectively.

\section{Statistical Analysis}

Box plot univariate analysis, principal component analysis (PCA), hierarchical cluster analysis (HCA), and discriminate analysis (DA) were performed by using SPSS ${ }^{\circledR}$ (v.17, IBM software).

\section{Results and Discussion}

\section{Evaluation of the Analytical Method}

Different analytical methods for the elemental analysis of dates have been reported (Al-Hooti et al. 1998; Tang et al. 2013; Ahmed et al. 1995; Elleuch et al. 2008; Khan et al. 2008; Al-Farsi et al. 2005; Sahari et al. 2007; Besbes et al. 2004; Mohamed 2000; Pillay et al. 2002; Rastegar et al. 2012; Williams et al. 2005). In general terms, most of the methodologies employed in the literature have not been validated. Some works (Khan et al. 2008; Al-Farsi et al. 2005) employed the AOAC 985.35 method, specifically developed for the analysis of $\mathrm{Ca}, \mathrm{Cu}, \mathrm{Fe}, \mathrm{K}, \mathrm{Mg}, \mathrm{Mn}, \mathrm{Na}$, and $\mathrm{Zn}$ in infant formula, enteral products, and pet foods by atomic absorption spectrometry (AAS). Among this group of techniques, flame atomic absorption spectrometry (FAAS) is the most widely reported for elemental date analysis (Ahmed et al. 1995; Elleuch et al. 2008; Khan et al. 2008; Besbes et al. 2004; Mohamed 2000). Nevertheless, the typical limits of detection exhibit by this technique makes it inappropriate to quantify elements at ultra-trace levels (Ebdon et al. 1998). Al-Farsi et al. (2005) used electrothermal atomic absorption spectrometry (ETAAS) to determine the elemental composition of dates. Although useful for ultra-trace elements, ETAAS is time-consuming due to its mono-element nature. For trace multielement analysis In these cases, the use of ICP-AES is recommended. Nevertheless, very few works have used this technique for the elemental analysis of dates (Sahari et al. 2007; Pillay et al. 2002; Williams et al. 2005).

Taking into account the above-made comments, the evaluation of the analytical method proposed in the present work is mandatory in order to ensure the quality of the results afforded. The method has been evaluated in terms of accuracy, precision, and LoD/LoQ. 
First, a recovery test was performed to estimate method accuracy because certified date material is not available. As it can be observed in Table 2, the average recoveries (95 \% confidence level, $n=5$ ) obtained for all analytes in the samples tested were almost complete, ranging between $93 \pm 7 \%$ ( $\mathrm{Sr}$ in seeds) and $109 \pm 6 \%$ ( $\mathrm{Cu}$ in flesh). Therefore, it can be concluded that (i) the method is free of interferences and (ii) no analyte losses are produced during the acid digestion step. No comparison with other date analysis methodologies can be performed due to the lack of data reported. Nevertheless, analyte losses during the sample treatment are expected to be reduced when using a closedvessel microwave digestion method when compared with those widely used in the literature (Kebbekus 2003 ), i.e., dry ashing procedure at temperatures above $500{ }^{\circ} \mathrm{C}$ (Ahmed et al. 1995; Elleuch et al. 2008; Khan et al. 2008; Al-Farsi et al. 2005; Besbes et al. 2004; Pillay et al. 2002) and open-vessel acid digestion (Mohamed 2000; Williams et al. 2005; Al-Hooti et al. 1998). Ali-Mohamed and Khamis ( 2004 ) also employed a closed-vessel microwave digestion procedure, but unfortunately, no accuracy data was provided by the authors.

\section{Table 2}

Average recovery values obtained after spiking four different date samples

\begin{tabular}{|l|l|l|l|}
\hline \multicolumn{1}{|c|}{ Technique } & Element & \multicolumn{1}{|c|}{ Flesh (\%) } & Seed (\%) \\
\hline ICP-AES & $\mathrm{Ca}$ & $96 \pm 5$ & $103 \pm 2$ \\
\hline & $\mathrm{Cu}$ & $109 \pm 6$ & $107 \pm 6$ \\
\hline & $\mathrm{Fe}$ & $108 \pm 5$ & $104 \pm 7$ \\
\hline & $\mathrm{Mg}$ & $102 \pm 3$ & $97 \pm 2$ \\
\hline & $\mathrm{Mn}$ & $108 \pm 6$ & $105 \pm 7$ \\
\hline & $\mathrm{Sr}$ & $94 \pm 5$ & $93 \pm 7$ \\
\hline ICP-MS & $\mathrm{Zn}$ & $106 \pm 4$ & $105 \pm 2$ \\
\hline & $\mathrm{As}$ & $99 \pm 5$ & $97 \pm 3$ \\
\hline & $\mathrm{Ba}$ & $96 \pm 2$ & $94 \pm 5$ \\
\hline & $\mathrm{Cd}$ & $95 \pm 3$ & $97 \pm 6$ \\
\hline & $\mathrm{Co}$ & $95 \pm 6$ & $98 \pm 2$ \\
\hline & $\mathrm{Cr}$ & $105 \pm 4$ & $99 \pm 3$ \\
\hline
\end{tabular}

Results are expressed as mean $\pm t s / \sqrt{n}$, where $t$ is the Student's $t$ (95\% confidence level), $s$ is the standard deviation, and $n$ is the number of replicates (5) 


\begin{tabular}{|l|l|l|l|}
\hline Technique & Element & Flesh (\%) & Seed (\%) \\
\hline & $\mathrm{Li}$ & $102 \pm 5$ & $99 \pm 6$ \\
\hline & $\mathrm{Ni}$ & $104 \pm 6$ & $101 \pm 3$ \\
\hline & $\mathrm{Pb}$ & $96 \pm 3$ & $99 \pm 6$ \\
\hline & $\mathrm{Se}$ & $97 \pm 4$ & $98 \pm 3$ \\
\hline & $\mathrm{V}$ & $95 \pm 4$ & $97 \pm 3$
\end{tabular}

Results are expressed as mean $\pm t s / \sqrt{n}$, where $t$ is the Student's $t$ (95\% confidence level), $s$ is the standard deviation, and $n$ is the number of replicates (5)

As regards the precision of the method, RSD values for most of the tested elements do not exceed 6-7\%. These values are of the same order of magnitude than those previously reported in the literature (Williams et al. 2005 ; Al-Farsi et al. 2005 ; Besbes et al. 2004 ).

Table 3 shows the method LoDs and LoQs estimated for the elements tested both in ICP-AES and ICP-MS. Obtained LoQs are low enough to determine most of the interest elements in the concentration levels expected in date samples (flesh and seeds). Unfortunately, no comparison with other analytical methodologies can be performed since LoDs neither for multi-element analysis of dates by ICP-based techniques nor by AAS ones have been previously reported in the literature.

Table 3

Method limits of detection and quantification in ICP-AES and ICP-MS

\begin{tabular}{|c|c|c|c|}
\hline Technique & Element & $\mathrm{LoD}(\mathrm{mg} / \mathrm{kg})$ & $\mathrm{LoQ}(\mathrm{mg} / \mathrm{kg})$ \\
\hline \multirow{9}{*}{ ICP-AES } & $\mathrm{Ca}$ & 0.2 & 0.6 \\
\hline & $\mathrm{Cu}$ & 0.1 & 0.3 \\
\hline & $\mathrm{Fe}$ & 0.1 & 0.3 \\
\hline & $\mathrm{K}$ & 0.6 & 2 \\
\hline & $\mathrm{Mg}$ & 0.01 & 0.04 \\
\hline & $\mathrm{Mn}$ & 0.02 & 0.05 \\
\hline & $\mathrm{Na}$ & 1.2 & 4 \\
\hline & $\mathrm{Sr}$ & 0.002 & 0.006 \\
\hline & $\mathrm{Zn}$ & 0.2 & 0.5 \\
\hline
\end{tabular}




\begin{tabular}{|c|c|c|c|}
\hline Technique & Element & LoD $(\mathrm{mg} / \mathrm{kg})$ & $\operatorname{LoQ}(\mathrm{mg} / \mathrm{kg})$ \\
\hline \multirow{10}{*}{ ICP-MS } & As & 0.01 & 0.04 \\
\hline & $\mathrm{Ba}$ & 0.001 & 0.009 \\
\hline & $\mathrm{Cd}$ & 0.0005 & 0.002 \\
\hline & Co & 0.01 & 0.04 \\
\hline & $\mathrm{Cr}$ & 0.005 & 0.02 \\
\hline & $\mathrm{Li}$ & 0.001 & 0.007 \\
\hline & $\mathrm{Ni}$ & 0.005 & 0.04 \\
\hline & $\mathrm{Pb}$ & 0.005 & 0.02 \\
\hline & $\mathrm{Se}$ & 0.02 & 0.1 \\
\hline & $\mathrm{V}$ & 0.003 & 0.008 \\
\hline
\end{tabular}

\section{Elemental Content}

Tables 4 and 5 show the results of the elemental analysis of all the date samples tested (flesh and seed, respectively). From these tables, four groups of elements can be distinguished attending to its concentration level: (i) major elements, with concentrations higher than 1,000 mg/kg (i.e., C, H, K, and N); (ii) minor elements, with concentrations between 100 and $1,000 \mathrm{mg} / \mathrm{kg}$ (i.e., $\mathrm{Ca}, \mathrm{Mg}$, and $\mathrm{Na}$ ); (iii) trace elements with concentrations in the $1-100 \mathrm{mg} / \mathrm{kg}$ range (i.e., $\mathrm{Cu}, \mathrm{Fe}, \mathrm{Mn}, \mathrm{Sr}$, and $\mathrm{Zn}$ ); and (iv) ultra-trace elements found in concentrations below $1 \mathrm{mg} / \mathrm{kg}$ (i.e., As, $\mathrm{Ba}, \mathrm{Cd}, \mathrm{Co}, \mathrm{Li}, \mathrm{Ni}, \mathrm{Pb}, \mathrm{Se}, \mathrm{Sr}$, and V). Among the last group of elements, some of them are present in concentrations below its LoQ.

\section{Table 4}

Results of the elemental analysis of flesh date samples

\section{Concentration}

\section{Element}

Elche

Tunisia

Results are expressed as mean $\pm t s / \sqrt{n}$, where $t$ is the Student's $t$ (95\% confidence replicates (5) 


\section{Concentration}

\begin{tabular}{|c|c|c|c|c|c|c|c|}
\hline \multirow[t]{2}{*}{ Element } & Elche & & & & & \multirow[b]{2}{*}{5} & Iuni \\
\hline & 1 & 2 & 3 & & & & $\begin{array}{l}\text { Deglet } \\
\text { Nour }\end{array}$ \\
\hline $\mathrm{C}$ & $\begin{array}{l}392,000 \\
\pm 900\end{array}$ & $\begin{array}{l}380,000 \\
\pm \\
10,000\end{array}$ & $\begin{array}{l}380,000 \\
\pm \\
20,000\end{array}$ & $\begin{array}{l}390,000 \\
\pm \\
24,000\end{array}$ & $\begin{array}{l}381,000 \\
\pm 8,000\end{array}$ & $\begin{array}{l}377,000 \\
\pm 8,000\end{array}$ & $\begin{array}{l}371,000 \\
\pm 8,000\end{array}$ \\
\hline $\mathrm{H}$ & $\begin{array}{l}68,000 \\
\pm 5,000\end{array}$ & $\begin{array}{l}70,000 \\
\pm 2,000\end{array}$ & $\begin{array}{l}67,000 \\
\pm 1,000\end{array}$ & $\begin{array}{l}71,000 \\
\pm 5,000\end{array}$ & $\begin{array}{l}68,000 \\
\pm 4,000\end{array}$ & $\begin{array}{l}69,000 \\
\pm 3,000\end{array}$ & $\begin{array}{l}65,800 \\
\pm 400\end{array}$ \\
\hline $\mathrm{N}$ & $\begin{array}{l}5,100 \pm \\
400\end{array}$ & $\begin{array}{l}6,900 \pm \\
500\end{array}$ & $\begin{array}{l}6,130 \pm \\
140\end{array}$ & $\begin{array}{l}6,100 \pm \\
800\end{array}$ & $\begin{array}{l}4,300 \pm \\
600\end{array}$ & $\begin{array}{l}6,800 \pm \\
900\end{array}$ & $\begin{array}{l}5,300 \pm \\
600\end{array}$ \\
\hline K & $\begin{array}{l}6,940 \pm \\
160\end{array}$ & $\begin{array}{l}5,360 \pm \\
160\end{array}$ & $\begin{array}{l}5,600 \pm \\
200\end{array}$ & $\begin{array}{l}5,140 \pm \\
150\end{array}$ & $\begin{array}{l}7,470 \pm \\
170\end{array}$ & $\begin{array}{l}4,600 \pm \\
100\end{array}$ & $\begin{array}{l}3,800 \pm \\
60\end{array}$ \\
\hline $\mathrm{Ca}$ & $787 \pm 8$ & $\begin{array}{l}1,100 \pm \\
30\end{array}$ & $931 \pm 7$ & $459 \pm 10$ & $527 \pm 10$ & $536 \pm 17$ & $261 \pm 14$ \\
\hline $\mathrm{Mg}$ & $709 \pm 10$ & $763 \pm 9$ & $857 \pm 11$ & $508 \pm 9$ & $615 \pm 9$ & $394 \pm 8$ & $272 \pm 8$ \\
\hline $\mathrm{Na}$ & $127 \pm 3$ & $139 \pm 3$ & $119 \pm 2$ & $106 \pm 4$ & $129 \pm 2$ & $265 \pm 6$ & $115 \pm 7$ \\
\hline $\mathrm{Fe}$ & $\begin{array}{l}5.7 \pm \\
0.2\end{array}$ & $\begin{array}{l}6.1 \pm \\
0.4\end{array}$ & $\begin{array}{l}4.2 \pm \\
0.2\end{array}$ & $\begin{array}{l}4.4 \pm \\
0.2\end{array}$ & $\begin{array}{l}2.3 \pm \\
0.1\end{array}$ & $\begin{array}{l}4.3 \pm \\
0.3\end{array}$ & $\begin{array}{l}2.3 \pm \\
0.2\end{array}$ \\
\hline $\mathrm{Cu}$ & $\begin{array}{l}5.5 \pm \\
0.5\end{array}$ & $\begin{array}{l}6.1 \pm \\
0.4\end{array}$ & $\begin{array}{l}2.9 \pm \\
0.2\end{array}$ & $\begin{array}{l}2.7 \pm \\
0.2\end{array}$ & $\begin{array}{l}2.1 \pm \\
0.1\end{array}$ & $\begin{array}{l}2.6 \pm \\
0.2\end{array}$ & $\begin{array}{l}0.7 \pm \\
0.0\end{array}$ \\
\hline $\mathrm{Mn}$ & $\begin{array}{l}2.7 \pm \\
0.2\end{array}$ & $\begin{array}{l}2.4 \pm \\
0.2\end{array}$ & $\begin{array}{l}1.9 \pm \\
0.1\end{array}$ & $\begin{array}{l}1.3 \pm \\
0.1\end{array}$ & $\begin{array}{l}2.2 \pm \\
0.1\end{array}$ & $\begin{array}{l}1.9 \pm \\
0.1\end{array}$ & $\begin{array}{l}1.2 \pm \\
0.1\end{array}$ \\
\hline $\mathrm{Sr}$ & $\begin{array}{l}2.8 \pm \\
0.1\end{array}$ & $\begin{array}{l}9.1 \pm \\
0.6\end{array}$ & $\begin{array}{l}13.0 \pm \\
0.4\end{array}$ & $\begin{array}{l}3.4 \pm \\
0.3\end{array}$ & $\begin{array}{l}1.6 \pm \\
0.1\end{array}$ & $\begin{array}{l}2.3 \pm \\
0.2\end{array}$ & $\begin{array}{l}1.1 \pm \\
0.1\end{array}$ \\
\hline $\mathrm{Zn}$ & $\begin{array}{l}4.3 \pm \\
0.2\end{array}$ & $\begin{array}{l}5.8 \pm \\
0.6\end{array}$ & $\begin{array}{l}3.0 \pm \\
0.1\end{array}$ & $\begin{array}{l}4.1 \pm \\
0.3\end{array}$ & $\begin{array}{l}2.3 \pm \\
0.1\end{array}$ & $\begin{array}{l}3.4 \pm \\
0.3\end{array}$ & $\begin{array}{l}1.4 \pm \\
0.1\end{array}$ \\
\hline As & $<\mathrm{LOQ}$ & $<\mathrm{LOQ}$ & $\begin{array}{l}0.051 \pm \\
0.003\end{array}$ & $<$ LOD & $<\mathrm{LOQ}$ & $<$ LOD & $<\mathrm{LOD}$ \\
\hline $\mathrm{Ba}$ & $\begin{array}{l}0.20 \pm \\
0.01\end{array}$ & $\begin{array}{l}0.033 \pm \\
0.001\end{array}$ & $\begin{array}{l}0.037 \pm \\
0.001\end{array}$ & $\begin{array}{l}0.032 \pm \\
0.001\end{array}$ & $\begin{array}{l}0.126 \pm \\
0.004\end{array}$ & $\begin{array}{l}0.032 \pm \\
0.002\end{array}$ & $\begin{array}{l}0.023 \pm \\
0.002\end{array}$ \\
\hline $\mathrm{Cd}$ & $\begin{array}{l}0.01 \pm \\
0.001\end{array}$ & $\begin{array}{l}0.0048 \\
\pm \\
0.0004\end{array}$ & $\begin{array}{l}0.0025 \\
\pm \\
0.0003\end{array}$ & $\begin{array}{l}0.0037 \\
\pm \\
0.0003\end{array}$ & $\begin{array}{l}0.013 \pm \\
0.001\end{array}$ & $\begin{array}{l}0.002 \pm \\
0.001\end{array}$ & $\begin{array}{l}0.004 \pm \\
0.001\end{array}$ \\
\hline Co & $\begin{array}{l}0.087 \pm \\
0.003\end{array}$ & $\begin{array}{l}0.048 \pm \\
0.001\end{array}$ & $\begin{array}{l}5.1 \pm \\
0.2\end{array}$ & $\begin{array}{l}0.115 \pm \\
0.008\end{array}$ & $\begin{array}{l}0.40 \pm \\
0.01\end{array}$ & $\begin{array}{l}0.15 \pm \\
0.01\end{array}$ & $\begin{array}{l}0.038 \pm \\
0.002\end{array}$ \\
\hline
\end{tabular}

Results are expressed as mean $\pm t s / \sqrt{n}$, where $t$ is the Student's $t$ (95\% confidence replicates (5) 


\section{Concentration}

\begin{tabular}{l|l|l|l|l|l|l|l}
\hline \multirow{2}{*}{ Element } & Elche & & & & & & \\
& & & & & & & \\
Tunisia
\end{tabular}

Results are expressed as mean $\pm t s / \sqrt{n}$, where $t$ is the Student's $t$ (95\% confidence replicates (5)

\section{Table 5}

Results of the elemental analysis of seed date samples

Concentration

\begin{tabular}{|c|c|c|c|c|c|c|c|}
\hline \multirow{2}{*}{ Element } & Elche & & & & & & Tunisia \\
\hline & 1 & 2 & 3 & 4 & 5 & 6 & $\begin{array}{c}\text { Deglet } \\
\text { Nour }\end{array}$ \\
\hline $\mathrm{C}$ & $\begin{array}{l}290,000 \\
\pm \\
11,000\end{array}$ & $\begin{array}{l}326,000 \\
\pm \\
14,000\end{array}$ & $\begin{array}{l}330,000 \\
\pm \\
30,000\end{array}$ & $\begin{array}{l}374,000 \\
\pm \\
12,000\end{array}$ & $\begin{array}{l}364,000 \\
\pm \\
13,000\end{array}$ & $\begin{array}{l}373,000 \\
\pm \\
17,000\end{array}$ & $\begin{array}{l}433,000 \\
\pm 6,000\end{array}$ \\
\hline $\mathrm{H}$ & $\begin{array}{l}76,000 \\
\pm 4,000\end{array}$ & $\begin{array}{l}68,000 \\
\pm 6,000\end{array}$ & $\begin{array}{l}57,700 \\
\pm 1,400\end{array}$ & $\begin{array}{l}63,000 \\
\pm 2,000\end{array}$ & $\begin{array}{l}56,000 \\
\pm 3,000\end{array}$ & $\begin{array}{l}56,000 \\
\pm 8,000\end{array}$ & $\begin{array}{l}65,000 \\
\pm 5,000\end{array}$ \\
\hline $\mathrm{N}$ & $\begin{array}{l}6,300 \pm \\
200\end{array}$ & $\begin{array}{l}7,400 \pm \\
400\end{array}$ & $\begin{array}{l}6,500 \pm \\
200\end{array}$ & $\begin{array}{l}8,700 \pm \\
400\end{array}$ & $\begin{array}{l}6,800 \pm \\
500\end{array}$ & $\begin{array}{l}7,000 \pm \\
300\end{array}$ & $\begin{array}{l}7,800 \pm \\
300\end{array}$ \\
\hline
\end{tabular}

Results are expressed as mean $\pm t s / \sqrt{n}$, where $t$ is the Student's $t$ (95\% confidence replicates (5) 


\section{Concentration}

\begin{tabular}{|c|c|c|c|c|c|c|c|}
\hline \multirow{2}{*}{ Element } & Elche & & & & & & Tunisia \\
\hline & 1 & 2 & 3 & 4 & 5 & 6 & $\begin{array}{c}\text { Deglet } \\
\text { Nour }\end{array}$ \\
\hline K & $\begin{array}{l}1,124 \pm \\
14\end{array}$ & $\begin{array}{l}1,030 \pm \\
20\end{array}$ & $\begin{array}{l}1,390 \pm \\
80\end{array}$ & $\begin{array}{l}1,090 \pm \\
50\end{array}$ & $\begin{array}{l}1,070 \pm \\
20\end{array}$ & $930 \pm 30$ & $\begin{array}{l}1,330 \pm \\
50\end{array}$ \\
\hline $\mathrm{Ca}$ & $208 \pm 9$ & $156 \pm 11$ & $256 \pm 13$ & $186 \pm 15$ & $160 \pm 10$ & $222 \pm 10$ & $81 \pm 5$ \\
\hline $\mathrm{Mg}$ & $482 \pm 10$ & $476 \pm 8$ & $509 \pm 8$ & $448 \pm 13$ & $542 \pm 2$ & $454 \pm 11$ & $365 \pm 11$ \\
\hline $\mathrm{Na}$ & $91 \pm 3$ & $94 \pm 5$ & $85 \pm 5$ & $91 \pm 5$ & $95 \pm 3$ & $102 \pm 4$ & $80 \pm 3$ \\
\hline $\mathrm{Fe}$ & $\begin{array}{l}6.9 \pm \\
0.2\end{array}$ & $\begin{array}{l}6.9 \pm \\
0.5\end{array}$ & $\begin{array}{l}6.6 \pm \\
0.3\end{array}$ & $\begin{array}{l}5.3 \pm \\
0.2\end{array}$ & $\begin{array}{l}5.5 \pm \\
0.3\end{array}$ & $\begin{array}{l}9.0 \pm \\
0.4\end{array}$ & $\begin{array}{l}4.9 \pm \\
0.4\end{array}$ \\
\hline $\mathrm{Cu}$ & $\begin{array}{l}3.2 \pm \\
0.3\end{array}$ & $\begin{array}{l}4.2 \pm \\
0.4\end{array}$ & $\begin{array}{l}3.9 \pm \\
0.4\end{array}$ & $\begin{array}{l}3.0 \pm \\
0.2\end{array}$ & $\begin{array}{l}4.1 \pm \\
0.2\end{array}$ & $\begin{array}{l}3.5 \pm \\
0.2\end{array}$ & $\begin{array}{l}1.3 \pm \\
0.1\end{array}$ \\
\hline $\mathrm{Mn}$ & $\begin{array}{l}4.8 \pm \\
0.2\end{array}$ & $\begin{array}{l}3.4 \pm \\
0.1\end{array}$ & $\begin{array}{l}4.0 \pm \\
0.2\end{array}$ & $\begin{array}{l}2.6 \pm \\
0.2\end{array}$ & $\begin{array}{l}4.3 \pm \\
0.1\end{array}$ & $\begin{array}{l}4.2 \pm \\
0.2\end{array}$ & $\begin{array}{l}3.1 \pm \\
0.1\end{array}$ \\
\hline $\mathrm{Sr}$ & $\begin{array}{l}0.28 \pm \\
0.02\end{array}$ & $\begin{array}{l}0.84 \pm \\
0.08\end{array}$ & $\begin{array}{l}3.44 \pm \\
0.25\end{array}$ & $\begin{array}{l}0.58 \pm \\
0.05\end{array}$ & $\begin{array}{l}0.25 \pm \\
0.02\end{array}$ & $\begin{array}{l}0.52 \pm \\
0.05\end{array}$ & $\begin{array}{l}0.21 \pm \\
0.02\end{array}$ \\
\hline $\mathrm{Zn}$ & $\begin{array}{l}5.2 \pm \\
0.2\end{array}$ & $\begin{array}{l}5.7 \pm \\
0.1\end{array}$ & $\begin{array}{l}5.4 \pm \\
0.4\end{array}$ & $\begin{array}{l}5.5 \pm \\
0.5\end{array}$ & $\begin{array}{l}5.6 \pm \\
0.3\end{array}$ & $\begin{array}{l}5.3 \pm \\
0.5\end{array}$ & $\begin{array}{l}3.9 \pm \\
0.3\end{array}$ \\
\hline As & $\begin{array}{l}0.042 \pm \\
0.003\end{array}$ & $\begin{array}{l}0.089 \pm \\
0.008\end{array}$ & $<\mathrm{LOQ}$ & $<\mathrm{LOQ}$ & $<\mathrm{LOQ}$ & $<\mathrm{LOQ}$ & $<\mathrm{LOD}$ \\
\hline $\mathrm{Ba}$ & $\begin{array}{l}0.160 \pm \\
0.004\end{array}$ & $\begin{array}{l}0.052 \pm \\
0.003\end{array}$ & $\begin{array}{l}0.067 \pm \\
0.002\end{array}$ & $\begin{array}{l}0.014 \pm \\
0.001\end{array}$ & $<\mathrm{LOQ}$ & $\begin{array}{l}0.019 \pm \\
0.001\end{array}$ & $\begin{array}{l}0.011 \pm \\
0.001\end{array}$ \\
\hline $\mathrm{Cd}$ & $\begin{array}{l}0.011 \pm \\
0.001\end{array}$ & $\begin{array}{l}0.0037 \\
\pm \\
0.0002\end{array}$ & $\begin{array}{l}0.012 \pm \\
0.01\end{array}$ & $<\mathrm{LOQ}$ & $<\mathrm{LOQ}$ & $<\mathrm{LOQ}$ & $<\mathrm{LOD}$ \\
\hline $\mathrm{Co}$ & $\begin{array}{l}3.20 \pm \\
0.03\end{array}$ & $\begin{array}{l}1.28 \pm \\
0.07\end{array}$ & $\begin{array}{l}1.35 \pm \\
0.05\end{array}$ & $\begin{array}{l}0.57 \pm \\
0.09\end{array}$ & $\begin{array}{l}0.87 \pm \\
0.03\end{array}$ & $\begin{array}{l}1.03 \pm \\
0.06\end{array}$ & $\begin{array}{l}0.075 \pm \\
0.004\end{array}$ \\
\hline $\mathrm{Cr}$ & $\begin{array}{l}0.30 \pm \\
0.01\end{array}$ & $\begin{array}{l}0.153 \pm \\
0.006\end{array}$ & $\begin{array}{l}0.167 \pm \\
0.007\end{array}$ & $\begin{array}{l}0.105 \pm \\
0.004\end{array}$ & $\begin{array}{l}0.072 \pm \\
0.003\end{array}$ & $\begin{array}{l}0.084 \pm \\
0.006\end{array}$ & $\begin{array}{l}0.088 \pm \\
0.007\end{array}$ \\
\hline $\mathrm{Li}$ & $<\mathrm{LOQ}$ & $<\mathrm{LOQ}$ & $<\mathrm{LOQ}$ & $<\mathrm{LOQ}$ & $<\mathrm{LOD}$ & $<$ LOQ & $<\mathrm{LOD}$ \\
\hline $\mathrm{Ni}$ & $\begin{array}{l}0.48 \pm \\
0.01\end{array}$ & $\begin{array}{l}0.471 \pm \\
0.007\end{array}$ & $\begin{array}{l}0.36 \pm \\
0.01\end{array}$ & $\begin{array}{l}0.34 \pm \\
0.01\end{array}$ & $\begin{array}{l}0.352 \pm \\
0.008\end{array}$ & $\begin{array}{l}0.69 \pm \\
0.03\end{array}$ & $\begin{array}{l}0.19 \pm \\
0.01\end{array}$ \\
\hline
\end{tabular}

Results are expressed as mean $\pm t s / \sqrt{n}$, where $t$ is the Student's $t$ (95\% confidence replicates (5) 
Concentration

\begin{tabular}{|c|c|c|c|c|c|c|c|}
\hline \multirow{2}{*}{ Element } & Elche & & & & & & Tunisia \\
\hline & 1 & 2 & 3 & 4 & 5 & 6 & $\begin{array}{l}\text { Deglet } \\
\text { Nour }\end{array}$ \\
\hline $\mathrm{Pb}$ & $\begin{array}{l}0.027 \pm \\
0.001\end{array}$ & $\begin{array}{l}0.020 \pm \\
0.001\end{array}$ & $\begin{array}{l}0.113 \pm \\
0.006\end{array}$ & $<\mathrm{LOD}$ & $<\mathrm{LOD}$ & $<\mathrm{LOQ}$ & $<$ LOD \\
\hline $\mathrm{Se}$ & $<\mathrm{LOQ}$ & $\begin{array}{l}0.110 \pm \\
0.004\end{array}$ & $<\mathrm{LOQ}$ & $<\mathrm{LOQ}$ & $<$ LOD & $<\mathrm{LOQ}$ & $<\mathrm{LOQ}$ \\
\hline $\mathrm{V}$ & $\begin{array}{l}0.019 \pm \\
0.001\end{array}$ & $\begin{array}{l}0.021 \pm \\
0.002\end{array}$ & $<\mathrm{LOQ}$ & $<\mathrm{LOQ}$ & $<\mathrm{LOQ}$ & $<\mathrm{LOD}$ & $\begin{array}{l}0.009 \pm \\
0.001\end{array}$ \\
\hline
\end{tabular}

Results are expressed as mean $\pm t s / \sqrt{n}$, where $t$ is the Student's $t$ (95\% confidence replicates (5)

The elemental concentration levels obtained using the proposed method (Tables 4 and 5) are, in general terms, in agreement with those reported in the literature. A further detailed comparison is not possible due to the huge variability of the data previously published. Al-Farsi and Lee (2008b) pointed out the wide concentration range (up to two orders of magnitude) reported for some elements in dates (e.g., Ca, 50-570 mg/kg; K, 3,450-8,820 mg/kg; Mg, $340-540 \mathrm{mg} / \mathrm{kg} ; \mathrm{Na}, 18-1,760 \mathrm{mg} / \mathrm{kg}$ ). The lack of the consistency between the reported data can be attributed to the following: (1) differences in the geographical origin, variety, and/or ripening stage of the date samples, and/or (2) the use of unappropriated analytical methodologies. The above mentioned data variability can be a cause of concern when dealing with toxic elements. Thus, for instance, $\mathrm{Se}$ is an essential element but toxic when present at high concentrations in foods. Some authors reported significant amounts of selenium in dates, i.e., $1.5-5.3 \mathrm{mg} / \mathrm{kg}$ (Al-Farsi et al. 2005 ; Al-Showiman et al. 1994). Taking into account the high consumption of dates in some countries (i.e., $114 \mathrm{~g} /$ day in the United Arab Emirates) (Ismail et al. 2006), the daily intake of Se could be as high as $0.6 \mathrm{mg}$, i.e., 1.5-fold the tolerable upper level per day $(0.4 \mathrm{mg})$. Results in Table 4 reveal that Se concentrations are, in most of the cases, below the method LoQ $(0.11 \mathrm{mg} / \mathrm{kg})$. These results, which are in agreement with those reported by Williams et al. (2005), indicated that the intake of $100 \mathrm{~g}$ of dates would provide up to $25 \%$ of the daily recommended dietary allowance of Se (i.e., $0.050 \mathrm{mg}$ ). Although the LoQ obtained for Se in ICP-MS (Table 3 ) can be considered low enough for 
date samples, the use of alternative sample introduction systems and/or the use of collision cell technology (CCT) would be advisable in order to improve the detection capability of the technique.

Results in Tables 4 and 5 indicate that Elche's dates afford, in general terms, higher concentrations of $\mathrm{Ba}, \mathrm{Cd}, \mathrm{Co}, \mathrm{Cr}$, and $\mathrm{Ni}$ in both date flesh and seeds than the remaining samples. These observations are confirmed by a box plot univariate analysis of the data and could be explained taking into account the important industrial activity traditionally developed in Elche (e.g., shoes manufacturing and leather tanning).

When comparing the results shown in Tables 4 and 5, it can be derived that, in general terms, the elemental content of date flesh is higher than that in seeds. This statement is true for all the elements tested with the exception of $\mathrm{Co}, \mathrm{Cr}, \mathrm{Mn}$, and $\mathrm{Ni}$.

\section{Multivariate Analysis}

Univariate statistics is not an enough tool to obtain an overview of a complex data matrix such as that presented in Tables 4 and 5. In these cases, the use of multivariate analysis techniques is recommended. To perform this analysis, the results for 18 elements (i.e., $\mathrm{Ba}, \mathrm{C}, \mathrm{Ca}, \mathrm{Cd}, \mathrm{Co}, \mathrm{Cr}, \mathrm{Cu}, \mathrm{Fe}, \mathrm{H}, \mathrm{K}, \mathrm{Li}, \mathrm{Mg}$, $\mathrm{Mn}, \mathrm{N}, \mathrm{Na}, \mathrm{Ni}, \mathrm{Sr}$, and $\mathrm{Zn}$ ) were used. The remaining four elements registered (i.e., $\mathrm{As}, \mathrm{Pb}, \mathrm{Se}$, and $\mathrm{V}$ ) were rejected since afforded, in most of the cases, concentrations below its respective LoQ. Elemental composition data obtained for date flesh (Table 4) and seed (Table 5) were analyzed independently.

\section{Principal Component Analysis (PCA)}

The information for the abovementioned 18 elements were analyzed using PCA. The number of significant principal components was selected on the basis of the Kaiser criterion with eigenvalue higher than 1. The PCA models obtained contain four components in the case of flesh and three for seed and together explained the 82.86 and $82.97 \%$ of the data total variance, respectively. For date flesh, the first principal component (PC1) explained $35.4 \%$ and the second component (PC2) explained $26.0 \%$. For date seeds, PC1 and PC2 explained 39.0 and $27.6 \%$, respectively.

Figure 1 shows the scatterplot of the PC1 and PC2 component scores of the date flesh (Fig. 1a) and seed (Fig. 1b). It is interesting to note that in both cases, the score plot allows to discriminate between the samples from Spain 
and the remaining ones. Thus, Fig. 1a shows that the samples from Elche can be easily identified using the flesh elemental composition, since all of them have PC2 values higher than zero. This situation is related to the fact that some of the elements showing the highest weighting on PC2 component ( $\mathrm{Ba}$, $\mathrm{Ca}, \mathrm{Cd}, \mathrm{Co}, \mathrm{Cr}, \mathrm{K}, \mathrm{Mg}, \mathrm{Na}, \mathrm{Ni}$, and $\mathrm{Sr}$ ) are those found in higher concentrations in the dates from Elche. Results in Fig. 1 also reveal that the foreign date samples are gathered into two groups: one of them including the samples from Tunisia, Saudi Arabia, Algeria, and Israel (Hayani and Medjool) and the other one including those from Iran and Israel (Barhi). It would be desirable to analyze a higher number of samples with certified origin and/or variety. Unfortunately, the availability of date samples from different origins is limited due to the restrictive Spanish and European import normative.

Fig. 1

Scatterplot of the PC1 and PC2 component scores of $\mathbf{a}$ date flesh and $\mathbf{b}$ date seed. Samples:

) Elche1; (

) Elche2;

) Elche3; (

) Elche4; (

) Elche5; (

) Elche6; (

) Israel Barhi; (

) Israel Medjool;

) Israel Hayani; (

) Tunisia Deglet Nour;

$+$

) Algeria Deglet Nour; (

*

) Saudi Perny;

) Iran All this text and symbols in the same line: see the original Figure caption 


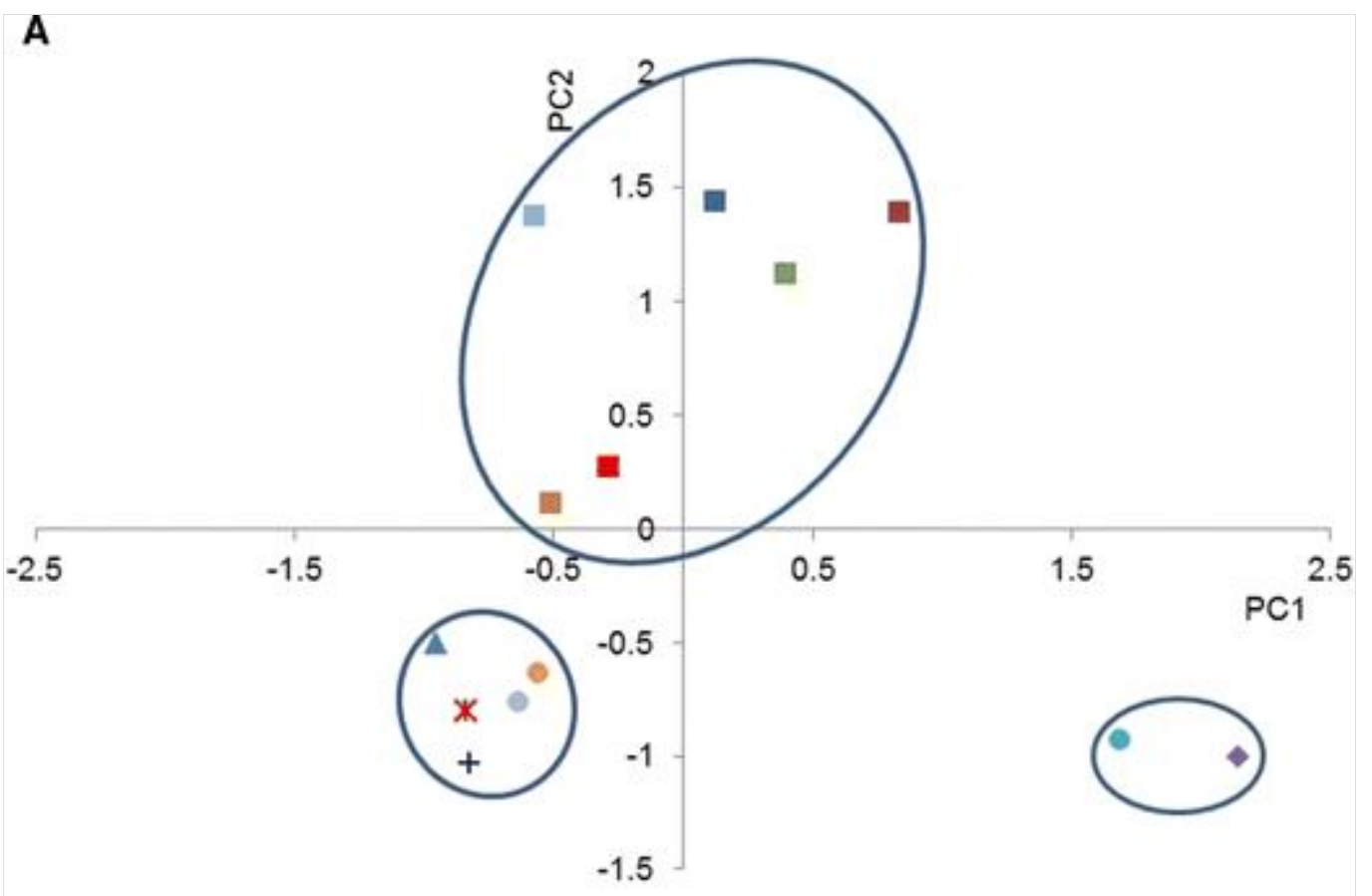

B

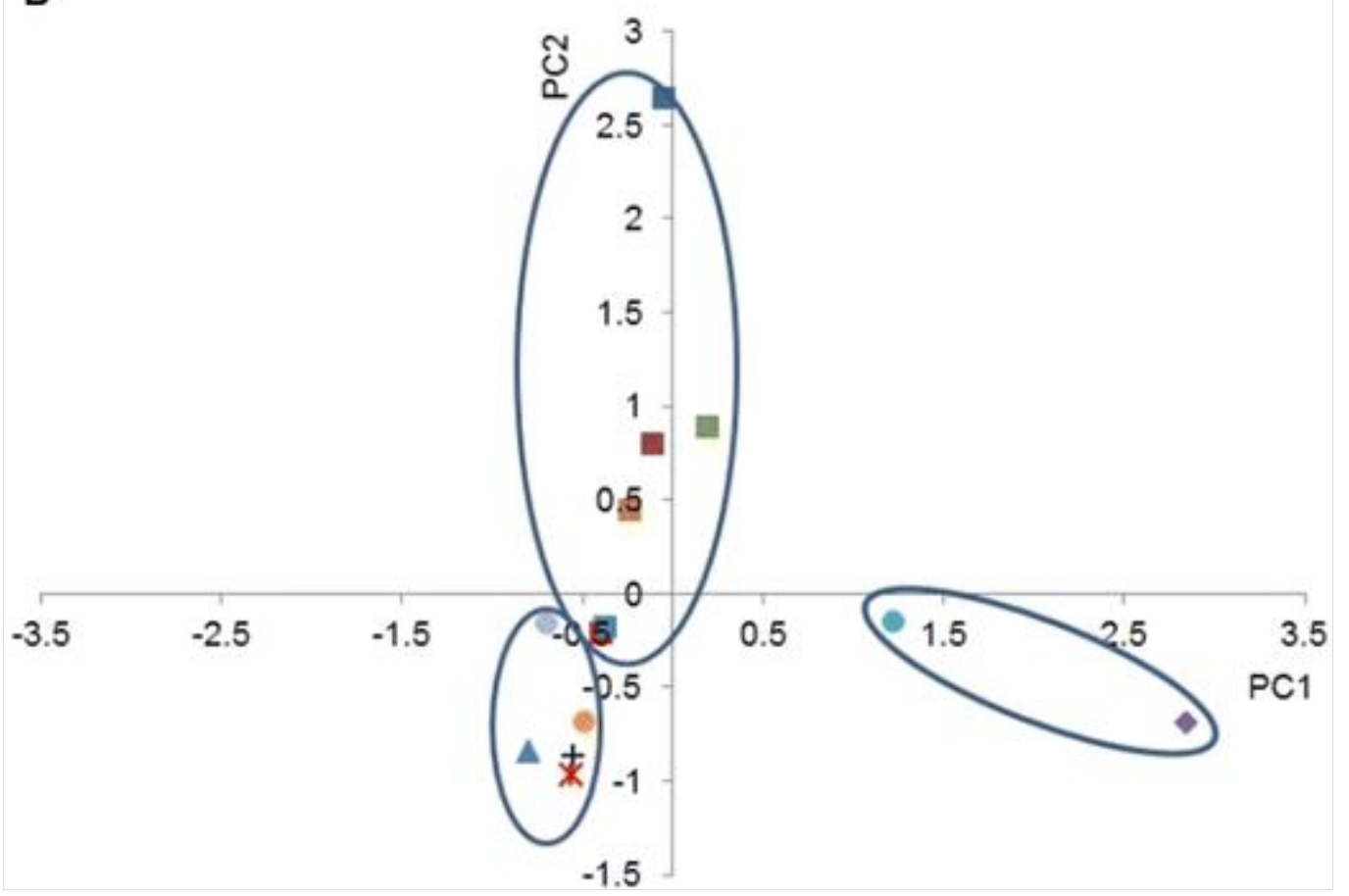

\section{Hierarchical Cluster Analysis}

Figure 2 shows the dendrograms obtained for flesh (Fig. 2a) and seed (Fig. 2b) samples. In both cases, data show a strong clustering behavior with high level of similarities for local varieties (flesh and seed). In agreement with the results obtained using PCA, flesh date samples were clearly separated into three groups (Fig. 2a): (i) Spain; (ii) Tunisia, Saudi Arabia, Algeria, and Israel (Hayani and Medjool); and (iii) Iran and Israel (Barhi). Similar results are obtained using the information for date seeds (Fig. 2b) although one sample (Israel Hayani) was classified incorrectly. 
Fig. 2

Dendrogram from the hierarchical cluster analysis for date samples of a flesh and $\mathbf{b}$ seed

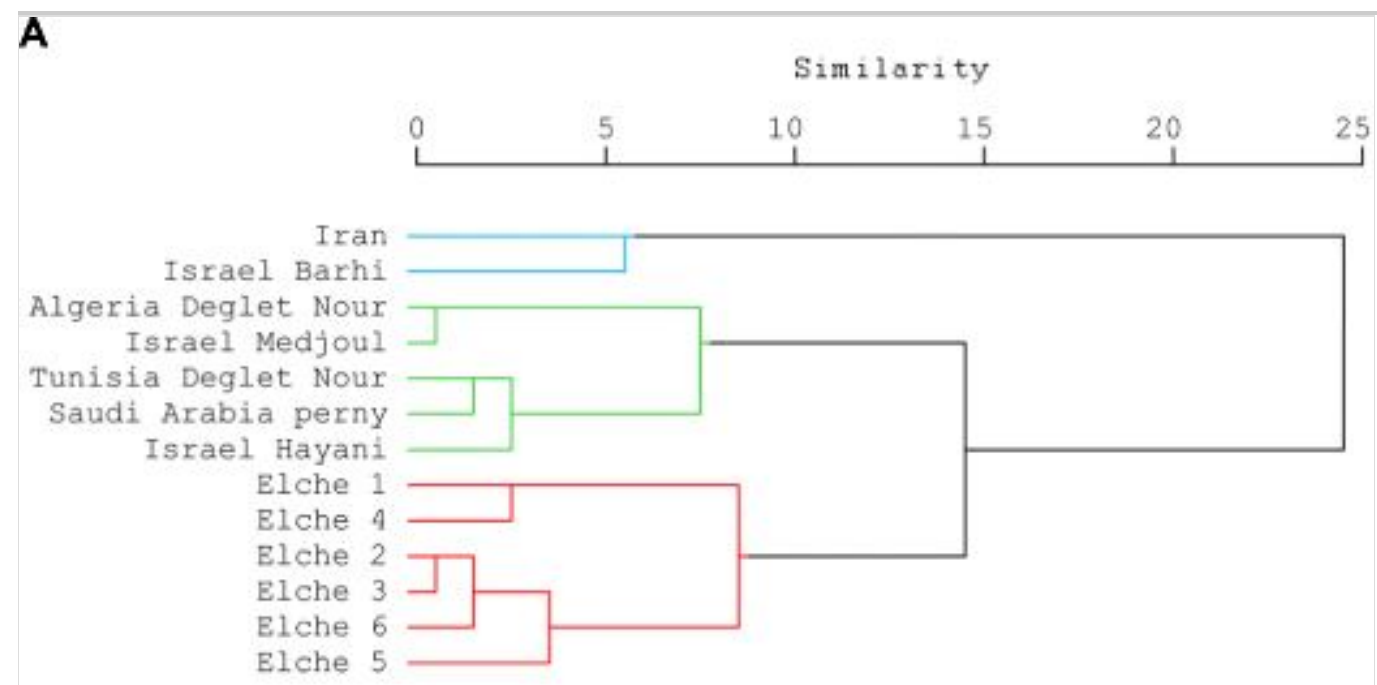

B

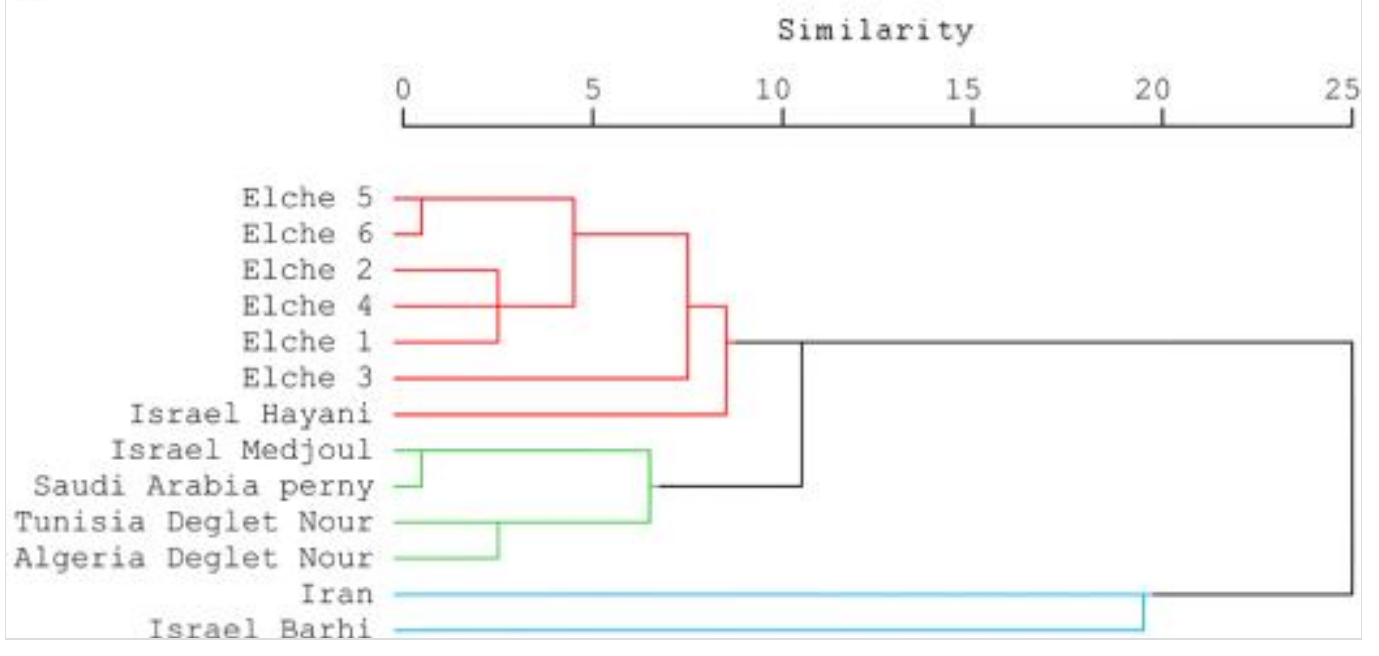

\section{Discriminate Analysis (LDA)}

A discriminant analysis was subsequently performed using stepwise inclusion procedure for the selection of variables (Díaz et al. 2003). LDA was performed using a step-by-step procedure and using the criterion of Wilks (Tabachnick and Fidell 1992). The discriminant information can be grouped into the two first discriminate functions. In the case of flesh (Fig. 3a), the first function explains the $91 \%$ of the differences between groups and the second one the remaining $9 \%$. For seeds (Fig. 3b), both functions explain the 86 and $13 \%$ of the group differences, respectively. As it can be observed in Fig. 3, LDA allows differentiating the Spanish samples from the remaining ones. It is also interesting to note that using LDA, all the samples from Israel are classified in a separate group. For both groups, the percentage of correct 
classification is $100 \%$ (irrespective of the data source used, i.e., flesh or seeds). Figure 3 also reveals a third group constituted by the samples of Tunisia, Algeria, Saudi Arabian, and Iran (i.e., all the origins with just one samples tested).

\section{Fig. 3}

Canonical discriminant function plot for $\mathbf{a}$ flesh and b seed samples. Samples:

\section{) Elche 1; (}

) Elche2; (

) Elche3; (

) Elche4; (

) Elche5; (

) Elche6; (

) Israel Barhi; (

) Israel Medjool;

) Israel Hayani;

) Tunisia Deglet Nour;

) Algeria Deglet Nour;

*

) Saudi Perny;

) Iran. Symbols $\square, \bigcirc$, and $\diamond$ represent the centroids for the groups of samples from Spain, Israel, and the rest of the samples tested, respectively All this text and symbols in the same line: see the original Figure caption 


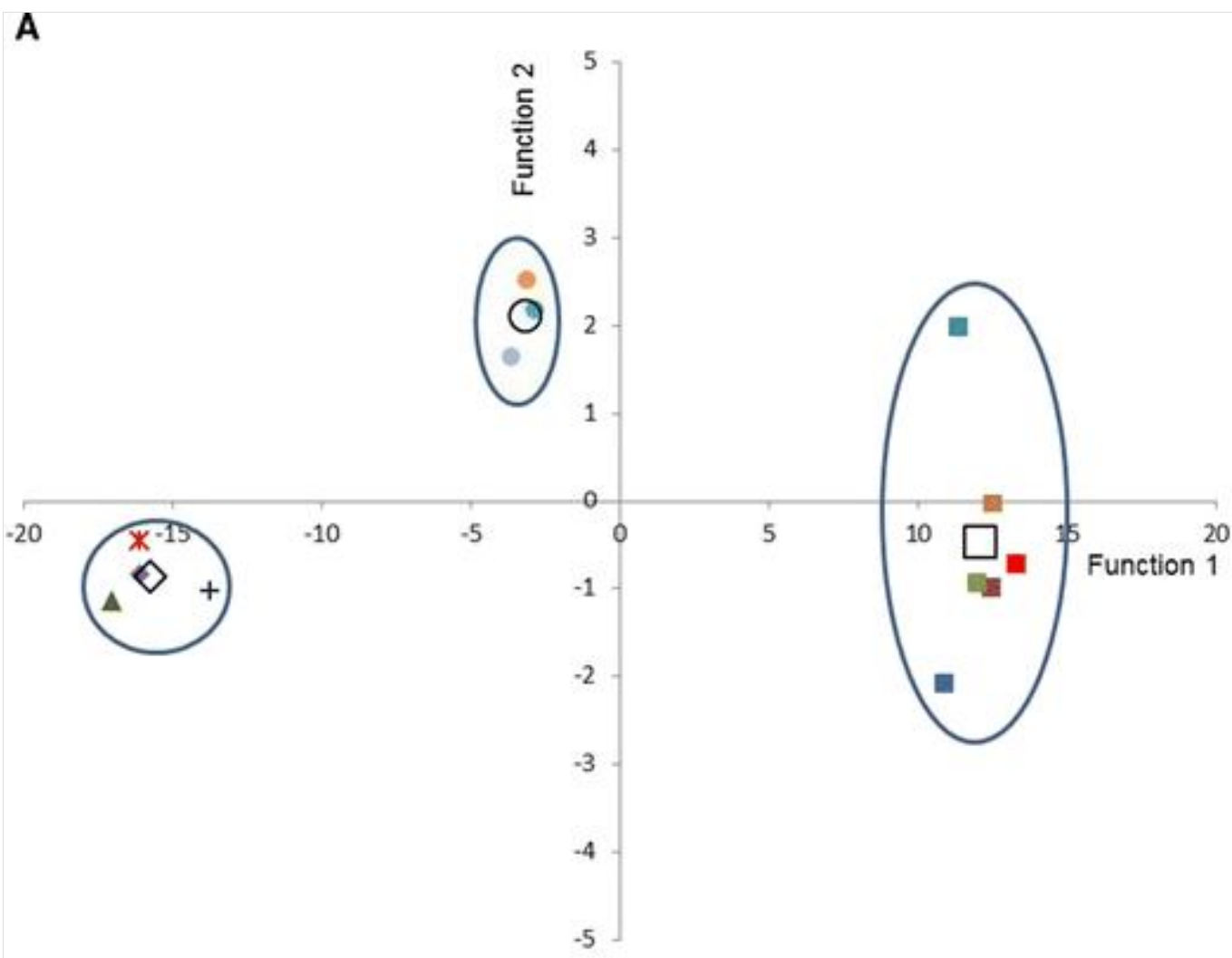

B
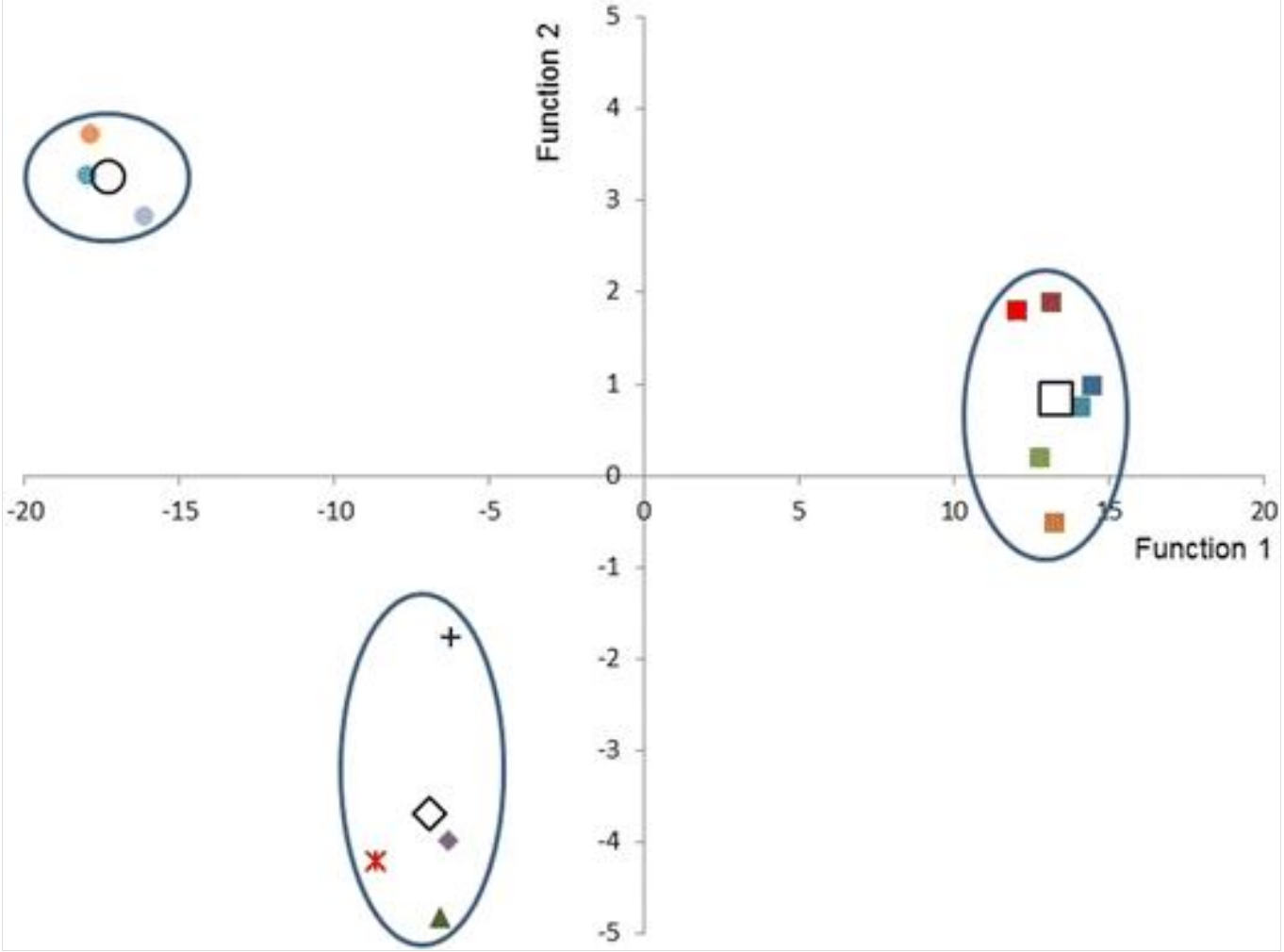

\section{Conclusions}

Mineral composition of Spanish dates is reported for the first time. A sensitive, accurate, and reproducible method based on microwave sample digestion and ICP-based detection has been employed. The elemental compositions (both in date flesh and seeds) have been used in multivariate 
statistical analysis (principal component, hierarchical cluster, and discriminant analyses). The results achieved indicate that the proposed approach can be successfully applied to discriminate the Spanish date samples from the rest of the samples tested.

\section{Conflict of Interest}

Shaymaa S. Abdrabo declares that she has no conflict of interest. Guillermo Grindlay declares that he has no conflict of interest. Luis Gras declares that he has no conflict of interest. Juan Mora declares that he has no conflict of interest. This article does not contain any studies with human or animal subjects.

\section{Electronic supplementary material}

Below is the link to the electronic supplementary material.

\section{ESM 1}

(DOCX $607 \mathrm{~kb}$ )

\section{References}

Abbas FMA, Foroogh B, Liong MT, Azhar ME (2008) Multivariate statistical analysis of antioxidants in dates (Phoenix dactylifera). Int Food Res J 15:193-200

AQ4

Ahmed IA, Ahmed AWK, Robinson RK (1995) Chemical composition of date varieties as influenced by the stage of ripening. Food Chem 54:305-309

Al-Farsi MA, Lee CY (2008a) Optimization of phenolics and dietary fibre extraction from date seeds. Food Chem 108:977-985

Al-Farsi MA, Lee CY (2008b) Nutritional and functional properties of dates. Crit Rev Food Sci Nutr 48:877-887

Al-Farsi MA, Alasalvar C, Morris A, Baron M, Shahidi F (2005)

Compositional and sensory characteristics of three native sun-dried date (Phoenix dactylifera L.) varieties grown in Oman. J Agric Food Chem 
Al-Hooti S, Sidhu JS, Qabazard H (1997) Physicochemical characteristics of five date fruit cultivars grown in the United Arab Emirates. Plant Food Hum Nutr 50:101-113

Al-Hooti S, Sidhu JS, Qabazard H (1998) Chemical composition of seeds of date fruit cultivars of United Arab Emirates. J Food Sci Technol $35: 44-46$

Ali-Mohamed AY, Khamis ASH (2004) Mineral ion content of the seeds of six cultivars of Bahraini date palm (Phoenix dactylifera). J Agric Food Chem 52:6522-6525

Al-Shahib W, Marshall RJ (2003) Fatty acid content of the seeds from 14 varieties of date palm Phoenix dactylifera L. Int J Food Sci Technol 38:709-712

Al-Showiman SS, Al-Tamrah SA, BaOsman AA (1994) Determination of selenium content in dates of some cultivars grown in Saudi Arabia. Int J Food Sci Nutr 45:29-33

Amira EA, Flamini G, Manel I, Ali F, Mohamed H, Noureddine HA, Lotfi A (2011) Chemical and aroma volatile composition of date palm (Phoenix dactylifera L.) fruits at three maturation stages. Food Chem 127:1744-1754

Amorós A, Pretel MT, Almansa MS, Botella MA, Zapata PJ, Serrano M (2009) Antioxidant and nutritional properties of date fruit from Elche Grove as affected by maturation and phenotypic variability of date palm. Food Sci Technol Int 15:65-72

AQ5

Besbes S, Blecker C, De Roanne C, Drira N, Attia H (2004) Date seeds: Chemical composition and characteristic profiles of the lipid fraction. Food Chem 84:577-584

Bigliari F, AlKarkhi AFM, Easa AM (2008) Antioxidant activity and phenolic content of various date palm (Phoenix dactylifera) fruits from Iran. Food Chem 107:1636-1641 
Bigliari F, AlKarkhi AFM, Easa AM (2009) Cluster analysis of antioxidant compounds in dates (Phoenix dactylifera): effect of long-term cold storage. Food Chem 112:998-1001

Boudries H, Kefalas P, Hornero-Méndez D (2007) Carotenoid composition of Algerian date varieties (Phoenix dactylifera) at different edible maturation stages. Food Chem 101:1372-1377

Díaz C, Conde JE, Estévez D, Pérez-Olivero SJ, Pérez-Trujillo JP (2003) Application of multivariate analysis and artificial neural networks for the differentiation of red wines from the Canary Islands according to the island of origin. J Agric Food Chem 51:4303-4307

Ebdon L, Evans HL, Fisher AS, Hill SJ (1998) An introduction to analytical atomic spectroscopy. Wiley, Chichester, England

Elleuch M, Besbes S, Roiseux O, Blecker C, Deroanne C, Drira NE, Attia $\mathrm{H}$ (2008) Date flesh: chemical composition and characteristics of the dietary fibre. Food Chem 111:676-682

FAO (Food and Agriculture Organization of the United Nations), Statistics Division (2014). http://faostat.fao.org/ . Accessed Jun 09/15/2014 AQ6 AQ7

Grindlay G, Mora J, de Loos-Vollebregt MTC, Vanhaecke F (2014) Evaluation of the multi-element capabilities of collision/reaction cell inductively coupled plasma-mass spectrometry in wine analysis. Talanta 128:379-385

Hamada JS, Hashim IB, Sharif AF (2002) Preliminary analysis and potential uses of date pits in foods. Food Chem 76:135-137

Ishurd O, Zahid M, Xiao P, Pan Y (2004) Protein and amino acids contents of Libyan dates at three stages of development. J Sci Food Agric 84:481-484

Ismail B, Henry J, Haffar I, Baalbaki R (2006) Date consumption and dietary significance in the United Arab Emirates. J Sci Food Agric 86:1196-1201 
Johnson DV, Al-Khayri JM, Jain SM (2013) Seedling date palms (Phoenix dactylifera L.) as genetic resources. Emir J Food Agric 25:809-830

Kebbekus BB (2003) Preparation of samples for metals analysis. In: Mitra $S$ (ed) Sample preparation techniques in analytical chemistry. Wiley, New Jersey, pp 227-270

Khan MN, Sarwar A, Wahab MF, Haleem R (2008) Physico-chemical characterization of date varieties using multivariate analysis. J Sci Food Agric 88:1051-1059

Martín-Sánchez AM, Cherif S, Vilella-Esplá J, Ben-Abda J, Kuri V, PérezÁlvarez JA, Sayas-Barberá E (2014a) Characterization of novel intermediate food products from Spanish date palm (Phoenix dactylifera L., cv. Confitera) co-products for industrial use. Food Chem 154:269-275

Martín-Sánchez AM, Cherif S, Ben-Abda J, Barber-Vallés X, PérezÁlvarez JA, Sayas-Barberá E (2014b) Phytochemicals in date co-products and their antioxidant activity. Food Chem 158:513-520

Mohamed AE (2000) Trace element levels in some kinds of dates. Food Chem 70:9-12

Mohamed Ahmed MVO, Bouna ZEO, Mohamed Lemine FM, Djeh TKO, Mokhtar T, Mohamed Salem AO (2011) Use of multivariate analysis to assess phenotypic diversity of date palm (Phoenix dactylifera L.) cultivars. Sci Hortic 127:367-371

Myhara RM, Karkalas J, Taylor MS (1999) The composition of maturing Omani dates. J Sci Food Agric 79:1345-1350

Pillay AE, Williams JR, El Mardi MO, Hassan SM, Al-Hamdi A (2002) Monitoring of cadmium in "on" and "off" date palms. Environ Int 28:273-276

Pohl P (2007) What do metals tell us about wine? Trends Anal Chem 26:941-949

Rastegar S, Rahemi M, Beghizadeh A, Gholami M (2012) Enzyme activity and biochemical changes of three date palm cultivars with different 
softening pattern during ripening. Food Chem 134:1279-1286

Sahari MA, Barzegar M, Radfar A (2007) Effect of varieties on the composition of dates (Phoenix dactylifera L.). Food Sci Technol Int 13:269-275

Tabachnick B, Fidell L (1992) Using multivariate statistics. Harper Collins Publishers, New York

Tang Z-X, Shi L-E, Aleid SM (2013) Date fruit: chemical composition, nutritional and medicinal values. J Sci Food Agric 93:2351-2361

Vanhaecke F, Vanhoe H, Dams R, Vandecasteele C (1992) The use of internal standards in ICP-MS. Talanta 39:737-742

Williams JR, Pillay AE, El Mardib MO, Al-Lawatia SMH, Al-Hamdi A (2005) Levels of selected metals in the Fard cultivar (date palm). J Arid Environ 60:211-225 